\title{
The Extracts of Some Marine Invertebrates and Algae Collected off the Coast Waters of Vietnam Induce the Inhibitory Effects on the Activator Protein-1 Transcriptional Activity in JB6 Cl41 Cells
}

\author{
S. N. Fedorov, ${ }^{1}$ V. B. Krasokhin, ${ }^{1}$ L. K. Shubina, ${ }^{1}$ S. A. Dyshlovoy, ${ }^{1}$ N. H. Nam, ${ }^{2}$ and C. V. Minh ${ }^{2}$ \\ ${ }^{1}$ Laboratory of Marine Natural Products Chemistry, G.B. Elyakov Pacific Institute of Bioorganic Chemistry, \\ Far-East Branch of the Russian Academy of Sciences, Prospect 100-let Vladivostoku 159, Vladivostok 690022, Russia \\ ${ }^{2}$ Institute of Marine Biochemistry, Vietnam Academy of Science and Technology, Hanoi, Vietnam
}

Correspondence should be addressed to S. N. Fedorov; fedorov@piboc.dvo.ru

Received 29 June 2012; Revised 6 December 2012; Accepted 19 December 2012

Academic Editor: Ana B. Martin-Diana

Copyright (C) 2013 S. N. Fedorov et al. This is an open access article distributed under the Creative Commons Attribution License, which permits unrestricted use, distribution, and reproduction in any medium, provided the original work is properly cited.

\begin{abstract}
It has previously been shown that inhibition of the transcriptional activity of the oncogenic nuclear factor AP-1 can result in cancer prevention. Marine invertebrates and alga are a rich source of natural compounds that possess various biological activities. The inhibitory effects of the extracts of Vietnamese marine organisms in relation to the AP-1 transcriptional activity were examined by the luciferase method using JB6 Cl41 cells stably expressing a luciferase reporter gene controlled by AP-1 DNA binding sequence. As was found, 71 species of marine sponges out of 148 species studied contain inhibitors of the AP-1 transcriptional activity. Therefore, marine organisms as a source of biologically active compounds have a great potential for isolation of the new cancer preventive compounds that inhibit the oncogenic AP-1 nuclear factor.
\end{abstract}

\section{Introduction}

The activator protein-1 (AP-1) transcription factor is a heterodimeric complex that contains members of the JUN, FOS, ATF, and MAF protein families. AP-1 activity is induced by a plethora of physiological stimuli and regulates a wide range of cellular processes, including cell migration, proliferation, differentiation, inflammation, apoptosis and survival, transformation, and tumor promotion [1-5]. The upregulation of such AP-1 proteins as c-FOS, FOSB, and cJUN was found to correlate with a positive effect on cell transformation [6-10]. The AP-1 has increased expression in different cancers including breast, ovarian, cervical, colorectal, lung, bladder, and many others [11-15]. Thus, AP1 has been considered primarily to be an oncogene. Later, some of the AP-1 proteins, such as Jun-B and c-Fos, were shown to have tumor-suppressor activity both in vitro and in vivo $[16,17]$. Activation of another AP-1 protein, c-Jun, is required for the induction of Fas L-mediated apoptosis in PC12 and human leukemia HL-60 cells $[18,19]$. Activation of both AP-1 and NF- $\kappa \mathrm{B}$ nuclear factors is necessary for DNA damaging agents- and ceramide-induced apoptosis in $\mathrm{T}$ lymphocytes and Jurkat T cells [20,21]. The balance between AP-1 family members, c-Jun, and ATF-2 governs the choice between differentiation and apoptosis in PC12 cells [22]. The ultimate fate of the cells relies on the relative abundance of AP-1 complex, the composition of the AP-1 dimers, cell type, and cellular environment [23].

AP-1 transcription factor plays a role in regulatory processes essential for the specific function of cells in the immune, endocrine, nervous, cardiovascular, and other physiological systems $[24,25]$, and therefore it participates not only in cancer but also in such diseases as cerebral ischaemia, stroke, seizure [26, 27], psoriasis [28], and mastitis [29].

Taken together, this suggests that AP-1 is a promising target for prevention and therapy in cancer and many other diseases [30].

Many works from our laboratory and other laboratoring clearly suggested that some cancer preventive and therapeutic 
compounds, including those of marine origin, can inhibit AP-1 activity, whereas other such compounds can induce it. For example, cancer preventive compounds resveratrol from grape skin, actinoporin RTX-A from sea anemones, steroidal glycoside LSG from starfishes are among agents that inhibit AP-1 activity [31-33]. On the other, hand anticancer drug vinblastine, cancer preventive flavonoids kaempferol and genistein, marine natural product 3-demethylubiquinone Q2 from ascidian Aplidium glabrum, and its synthetic analogs induce AP-1 activity [34-39].

In this study, the in vitro effects of ethanol extracts of 148 marine invertebrate species (mainly sponges) and algae on the basal AP-1-dependent transcriptional activity in mouse epidermal JB6 Cl41 cells were evaluated.

\section{Experimental}

2.1. Marine Invertebrates and Alga. The specimens of marine invertebrates and algae were collected off the coast of Vietnam at a depth of $2-440 \mathrm{~m}$ by scuba diving and trawling during the 34th scientific expedition onboard the research vessel "Academic Oparin" in May-June 2007 and were immediately extracted with ethanol. The animals and algae were identified by Dr. V. B. Krasokhin. The sponges having the same names in Table 1 belong to one and the same genus, but they may have different specific names, undetermined yet, and were collected at the different places of the coast of Vietnam. The voucher specimens are kept in the collection of G.B. Elyakov Pacific Institute of Bioorganic Chemistry of the Far Eastern Branch of the Russian Academy of Sciences, Vladivostok, Russia.

2.2. Cell Culture. The mouse epidermal JB6 Cl41 AP-1 cells were cultured in monolayers at $37 \mathrm{C}$ and $5 \% \mathrm{CO}_{2}$ in $\mathrm{MEM}$ containing $5 \%$ fetal bovine serum (FBS), 2 mM L-glutamine, $100 \mathrm{U} / \mathrm{mL}$ penicillin, and $100 \mathrm{mg} / \mathrm{mL}$ streptomycin [40].

2.3. MTS Cytotoxicity Assay. Each ethanol extract of a marine invertebrate or alga was evaporated to dryness. Then, the solutions of the dry extract residue in 5\% FBS/MEM with the residue concentrations of $1.0 ; 0.9 ; 0.8 ; 0.7 ; 0.6 ; 0.5 ; 0.4$; $0.25 ; 0.125$; and $0.0625 \mathrm{mg} / \mathrm{mL}$ were prepared. The effect of these solutions on JB6 Cl41 AP-1 cells viability was evaluated using MTS reduction into its formazan product [41] as described in [42]. In brief, the JB6 Cl41 AP-1 cells were cultured for $12 \mathrm{~h}$ in 96 -well plates $(6,000$ per well in $0.1 \mathrm{~mL}$ of $5 \% \mathrm{FBS} / \mathrm{MEM})$. The media was then replaced with fresh $5 \%$ FBS/MEM containing the studied substances at various concentrations in a total volume of $0.1 \mathrm{~mL}$ and the cells were incubated with obtained solutions for $22 \mathrm{~h}$. Then, $20 \mu \mathrm{L}$ of the MTS reagent was added into each well and MTS reduction was measured $2 \mathrm{~h}$ later spectrophotometrically at 492 and $690 \mathrm{~nm}$ as background using the Multiskan MS microplate reader (Labsystems, Finland). The solution with the first nontoxic concentration (more than $80 \%$ of living cells in the corresponding experiment) of an extract residue (see Table 1) was used in the luciferase assay (see Section 2.4).
TABLE 1: The effects of the extracts of the marine invertebrates and alga on AP-1-dependent transcriptional activity in JB6 Cl41 cells.

\begin{tabular}{|c|c|c|c|}
\hline Num. ${ }^{*}$ & Name $^{\mathrm{x}}$ & Conc. ${ }^{\mathfrak{E}} \mathrm{mg} / \mathrm{mL}$ & $\mathrm{AP}-1^{\ddagger}$ \\
\hline O14-34 & Callyspongia sp. & 0.6 & 103 \\
\hline O15-34 & Oscarella sp. & 0.5 & 94 \\
\hline O16-34 & Dysidea sp. & 0.5 & 100 \\
\hline O17-34 & Mycale sp. & 0.5 & 134 \\
\hline O18-34 & Chondrilla sp. & 0.6 & 110 \\
\hline O19-34 & Monanchora sp. & $0.125(0.24)^{* *}$ & 40 \\
\hline O20-34 & Haliclona sp. & 0.6 & 96 \\
\hline $\mathrm{O} 21-34$ & Spirastrella sp. & 0.4 & 111 \\
\hline $\mathrm{O} 22-34$ & Ascidian unidentified & 0.8 & 80 \\
\hline $\mathrm{O} 23-34$ & Petrosia sp. & 0.8 & 64 \\
\hline O24-34 & Demospongiae, unidentified & 0.6 & 88 \\
\hline $\mathrm{O} 25-34$ & Spirastrella sp. & 0.6 & 41 \\
\hline O26-34 & Callyspongia sp. & 0.5 & 71 \\
\hline O27-34 & Spongia sp. & 0.5 & 98 \\
\hline O28-34 & Mycale sp. & 0.8 & 106 \\
\hline O29-34 & Callyspongia sp. & 0.6 & 101 \\
\hline O30-34 & Chondrilla sp. & 0.6 & 89 \\
\hline O31-34 & Alga unidentified & 0.5 & 98 \\
\hline O33-34 & Callyspongia sp. & 0.5 & 89 \\
\hline O34-34 & Callyspongia sp. & 0.5 & 70 \\
\hline O35-34 & Xestospongia sp. & 0.6 & 29 \\
\hline O36-34 & Spongia sp. & 0.5 & 35 \\
\hline O37-34 & Spirastrella sp. & 0.5 & 122 \\
\hline O38-34 & $\begin{array}{l}\text { Demospongiae, Haplosclerida, } \\
\text { fam. unidentified }\end{array}$ & 0.5 & 90 \\
\hline O41-34 & Phakellia sp. & 0.7 & 59 \\
\hline $\mathrm{O} 42-34$ & Halichondria sp. & 0.5 & 74 \\
\hline O43-34 & Halichondria sp. & 0.4 & 125 \\
\hline O44-34 & Haliclona sp. & 0.6 & 105 \\
\hline O45-34 & Halichondria sp. & 0.6 & 75 \\
\hline O46-34 & Haliclona sp. & 0.6 & 93 \\
\hline O47-34 & Ascidian unidentified & 0.6 & 95 \\
\hline O48a-34 & Ascidian unidentified & 0.8 & 79 \\
\hline O48b-34 & Ascidian unidentified & 0.8 & 96 \\
\hline O49-34 & Echinoidea unidentified & 0.8 & 105 \\
\hline O50-34 & Pennatulacea unidentified & 0.5 & 91 \\
\hline O52-34 & Alga unidentified & 1.0 & 95 \\
\hline O53-34 & Alga unidentified & 0.6 & 76 \\
\hline O54-34 & Alga unidentified & 0.6 & 89 \\
\hline O55-34 & Alga unidentified & 0.7 & 93 \\
\hline O56-34 & Alga unidentified & 0.5 & 169 \\
\hline O57-34 & Petrosia sp. & 0.5 & 105 \\
\hline O58-34 & Demospongiae unidentified & $0.125(0.27)^{* *}$ & 19 \\
\hline O59-34 & Haliclona sp. & 0.8 & 74 \\
\hline O60-34 & Pachastrella sp. & $0.0625(0.17)^{* *}$ & 47 \\
\hline
\end{tabular}


TABLE 1: Continued.

\begin{tabular}{|c|c|c|c|}
\hline Num. $^{*}$ & $\mathrm{Name}^{\mathrm{x}}$ & Conc. ${ }^{£} \mathrm{mg} / \mathrm{mL}$ & $\mathrm{AP}-1^{¥}$ \\
\hline O61-34 & Spirastrella sp. & 0.5 & 73 \\
\hline O62-34 & Spongia sp. & 0.6 & 71 \\
\hline O63-34 & Spongia sp. & 0.5 & 102 \\
\hline O64-34 & Stelletta sp. & 0.5 & 62 \\
\hline O65-34 & Spirastrella sp. & $0.25(0.35)^{* *}$ & 52 \\
\hline O66-34 & Dysidea sp. & 0.125 & 77 \\
\hline O67-34 & Spongia sp. & 0.6 & 84 \\
\hline O68-34 & Algae unidentified & 0.5 & 67 \\
\hline O69-34 & Opistobranchia unidentified & 0.25 & 88 \\
\hline O70-34 & Opistobranchia unidentified & $0.125(0.22)^{* *}$ & 121 \\
\hline O71-34 & Opistobranchia unidentified & 0.8 & 96 \\
\hline O72-34 & Opistobranchia unidentified & 0.5 & 149 \\
\hline O73-34 & Spongia sp. & $0.0625(0.1)^{* *}$ & 137 \\
\hline O74-34 & Myxilla sp. & $0.125(0.23)^{* *}$ & 14 \\
\hline O75-34 & Spirastrella sp. & 0.4 & 108 \\
\hline O76-34 & Xestospongia sp. & 0.5 & 117 \\
\hline O77-34 & Stelletta sp. & 0.0625 & 91 \\
\hline O78-34 & Spongia sp. & $0.25(0.54)^{* *}$ & 38 \\
\hline O79-34 & Callyspongia sp. & 0.5 & 108 \\
\hline O81-34 & Gorgonian gen unidentified & 0.5 & 35 \\
\hline O82-34 & Gorgonian gen unidentified & 0.25 & 104 \\
\hline O83-34 & Ascidia & 0.6 & 91 \\
\hline O84-34 & Haliclona sp. & 0.6 & 74 \\
\hline O85-34 & Spirastrella sp. & 0.8 & 60 \\
\hline O86-34 & Halichondria sp. & 0.8 & 63 \\
\hline O87-34 & Spongia sp. & 0.8 & 60 \\
\hline O88-34 & Xestospongia sp. & 0.6 & 109 \\
\hline O89-34 & Clathria sp. & 0.8 & 105 \\
\hline O90-34 & Ascidian unidentified & 1.0 & 105 \\
\hline O92-34 & Spongia sp. & 0.6 & 93 \\
\hline O93-34 & Spirastrella sp. & 0.5 & 124 \\
\hline O94-34 & Spongia sp. & 0.6 & 77 \\
\hline O95-34 & Spongia sp. & 0.6 & 105 \\
\hline O98-34 & Crinoidea & 0.6 & 71 \\
\hline O99-34 & Demospongiae, unidentified & 0.8 & 93 \\
\hline O100-34 & Demospongiae, unidentified & 0.8 & 87 \\
\hline O101-34 & Demospongiae, unidentified & $0.25(0.4)^{* *}$ & 127 \\
\hline O102-34 & Spirastrella sp. & 0.5 & 84 \\
\hline O103-34 & Petrosia sp. & 0.5 & 54 \\
\hline O104-34 & Halichondria sp. & 0.5 & 104 \\
\hline O105-34 & Alga unidentified & 0.25 & 99 \\
\hline O106-34 & Alga unidentified & $0.0625(0.11)^{* *}$ & 169 \\
\hline O107-34 & Alga unidentified & 0.6 & 144 \\
\hline O115-34 & Crinoidea & $0.25(0.42)^{* *}$ & 73 \\
\hline O117-34 & Nudibranchia unidentified & $0.25(0.37)^{* *}$ & 77 \\
\hline O119-34 & Spirastrella sp. & 0.6 & 118 \\
\hline
\end{tabular}

TABLE 1: Continued.

\begin{tabular}{|c|c|c|c|}
\hline Num. $^{*}$ & Name $^{x}$ & Conc. $.^{£} \mathrm{mg} / \mathrm{mL}$ & $\mathrm{AP}-1^{7}$ \\
\hline O120-34 & Haliclona sp. & 0.6 & 88 \\
\hline O121-34 & Demospongiae unidentified & 0.6 & 111 \\
\hline O122-34 & Spongia sp. & 0.5 & 38 \\
\hline O123-34 & Callyspongia sp. & 0.0625 & 101 \\
\hline O124-34 & Axinella sp. & 0.6 & 52 \\
\hline O125-34 & Aplysina sp. & 0.6 & 60 \\
\hline O126-34 & Spongia sp. & 0.6 & 57 \\
\hline O127-34 & Spongia sp. & $0.0625(0.16)^{* *}$ & 46 \\
\hline O129-34 & Crinoidea unidentified & 0.6 & 84 \\
\hline O130-34 & Crinoidea unidentified & 0.5 & 90 \\
\hline O131-34 & Crinoidea unidentified & 0.125 & 83 \\
\hline O132-34 & Nudibranchia unidentified & 0.0625 & 84 \\
\hline O133-34 & Ascidian unidentified & $0.25(0.37)^{* *}$ & 73 \\
\hline O134-34 & Haliclona sp. & 0.0625 & 110 \\
\hline O135-34 & Callyspongia sp. & 0.5 & 135 \\
\hline O136-34 & Spongia sp. & 0.5 & 79 \\
\hline O137-34 & $\begin{array}{c}\text { Demospongiae } \\
\text { unidentified }\end{array}$ & 0.25 & 84 \\
\hline O140-34 & Spongia sp. & 0.8 & 41 \\
\hline O141-34 & Clathria sp. & 0.8 & 63 \\
\hline O145-34 & Callyspongia sp. & 0.8 & 43 \\
\hline O146-34 & Axinella sp. & 0.6 & 33 \\
\hline O149-34 & Suberites sp. & 0.8 & 83 \\
\hline O152-34 & Lithistida unidentified & 0.8 & 67 \\
\hline O153-34 & Halichondria sp. & 0.8 & 102 \\
\hline O154-34 & Penares sp. & $0.25(0.34)^{* *}$ & 37 \\
\hline O155-34 & Petrosia sp. & 0.8 & 67 \\
\hline O156-34 & Pheronema raphanus & 0.0625 & 90 \\
\hline O157-34 & Pachastrella sp. & 0.8 & 49 \\
\hline O158-34 & Lithistida unidentified & 0.8 & 75 \\
\hline O159-34 & Geodia sp. & 0.125 & 98 \\
\hline O160-34 & Demospongiae unidentified & 0.8 & 55 \\
\hline O162-34 & Halichondria sp. & 0.8 & 60 \\
\hline O163-34 & Spirastrella sp. & 0.5 & 101 \\
\hline O165-34 & Petrosia sp. & 0.8 & 53 \\
\hline O167-34 & Rhabdastrella globostellata & 0.5 & 37 \\
\hline O168-34 & Petrosia sp. & 0.125 & 81 \\
\hline O169-34 & Halichondria sp. & $0.25(0.48)^{* *}$ & 36 \\
\hline O170-34 & Acanthodendrilla sp. & $0.0625(0.1)^{* *}$ & 53 \\
\hline O171-34 & Callyspongia sp. & 0.8 & 30 \\
\hline O172-34 & Carteriospongia sp. & $0.0625(0.11)^{* *}$ & 19 \\
\hline O173-34 & Carteriospongia sp. & $0.25(0.32)^{* *}$ & 76 \\
\hline O174-34 & Axinella sp. & $0.25(0.41)^{* *}$ & 33 \\
\hline O175-34 & Halichondria sp. & $0.25(0.33)^{* *}$ & 66 \\
\hline O176-34 & Petrosia sp. & 0.125 & 110 \\
\hline O177-34 & Spongia sp. & $0.125(0.19)^{* *}$ & 54 \\
\hline
\end{tabular}


TABLe 1: Continued.

\begin{tabular}{lccc}
\hline Num. $^{*}$ & Name $^{\mathrm{x}}$ & Conc. $^{\mathfrak{E}} \mathrm{mg} / \mathrm{mL}$ & $\mathrm{AP}-1^{\mp}$ \\
\hline O178-34 & Petrosia sp. & 0.8 & $\mathbf{5 6}$ \\
O179-34 & Hyalonema sp. & 0.25 & 80 \\
O181-34 Porifera, Lithistida unidentified & 0.5 & $\mathbf{4 3}$ \\
O186-34 & Porifera, Calcarea, unidentified & 0.6 & $\mathbf{5 5}$ \\
O187-34 & Callyspongia sp. & 0.0625 & 101 \\
O188-34 & Agelas sp. & 0.8 & $\mathbf{5 0}$ \\
O189-34 & Axinella sp. & $0.0625(0.16)^{* *}$ & $\mathbf{6 7}$ \\
O192-34 & Agelas sp. & 0.8 & $\mathbf{4 7}$ \\
O193-34 & Petrosia sp. & 0.5 & $\mathbf{4 2}$ \\
O194-34 & Amphimedon sp. & $0.25(0.39)^{* *}$ & $\mathbf{4 2}$ \\
O196-34 & Spongia sp. & $0.125(0.23)^{* *}$ & $\mathbf{6 0}$ \\
O197-34 & Axinella sp. & 0.5 & $\mathbf{6 0}$ \\
O198-34 & Plakina sp. & 0.5 & $\mathbf{4 1}$ \\
\hline
\end{tabular}

*The number of the voucher specimen.

${ }^{\mathrm{x}}$ Systematical name of the specimen.

${ }^{E}$ Concentration of the extract dry residue in the MEM.

$¥$ AP-1-dependent transcriptional activity, percentage of the control.

${ }^{* *} \mathrm{IC}_{50}$.

\subsection{Luciferase Assay for AP-1-Dependent Transcriptional} Activity. The effect of the studied substances on AP-1 transcriptional activation was investigated in JB6 Cl41 cells stably expressing a luciferase reporter gene controlled by an AP1 DNA binding sequence as described earlier [43]. In brief, viable JB6 Cl41 AP-1 cells $\left(8 \times 10^{3}\right)$ suspended in $100 \mu \mathrm{L}$ of $5 \%$ FBS/MEM were added into each well of a 96 -well plate. Plates were incubated overnight and the media was then replaced with fresh 5\% FBS/MEM containing the extract residue at subtoxic concentration (see Section 2.3) in a total volume of $0.1 \mathrm{~mL}$ and the cells were incubated with the extract residue for $24 \mathrm{~h}$. Then, the cells were disrupted for $1 \mathrm{~h}$ at room temperature with lysis buffer $(0.1 \mathrm{M}$ potassium phosphate buffer at $\mathrm{pH}$ 7.8, 1\% Triton X-100, 1 mM DTT, 2 mM EDTA) and $30 \mu \mathrm{L}$ of lysate from each well were transferred into a plate for luminescent analysis and luciferase activity was measured. Results are expressed in Table 1 as an AP-1dependent transcriptional activity in percentage relative to untreated control cells (100\%).

\section{Results and Discussion}

In continuation of our search for cancer preventive compounds from marine organisms [32, 33, 38, 43, 44], we studied the influence of the extracts from 148 species of marine invertebrates and algae on the AP-1-dependent transcriptional activity in mouse epidermal JB6 Cl41 cells. The JB6 Cl41 cells undergo the malignant transformation under the treatment of EGF as a promoter. The transformation involves the activation of AP-1 nuclear factor which regulates the transcription of various genes related to inflammation, proliferation and metastasis. Thus, it can be said that the extracts which show the inhibition of the AP-1-dependent transcriptional activity in JB6 Cl41 cells may contain some cancer preventive compounds. To study the effects of the ethanol soluble substances from the studied species on the AP-1 transcriptional activity, we used the luciferase assay and JB6 Cl41 AP-1 cells stably expressing a luciferase reporter gene controlled by an AP-1 DNA binding sequence. The results of the study are presented in Table 1 .

We studied 148 species of marine invertebrates and algae, and there are 116 sponges, 7 ascidians, 10 species of algae, 1 species of Echinoidea, 4 species of Opistobranchia, 2 species of Nudibranchia, 2 species of Gorgonacea, 5 species of Crinoidea, 1 species of Pennatulacea. The extracts of 71 species studied showed inhibitory effects (less than $80 \%$ of activity in comparison to control) on AP-1-dependent transcriptional activity at noncytotoxic concentrations, whereas extracts of 12 species demonstrated activation (more than $120 \%$ of activity in comparison to control) of the AP1 nuclear factor in JB6 Cl41 cells. As shown in Table 1, sponges, belonging to genera Spongia, Petrosia, Halichondria, Callyspongia, Spirastrella, and Axinella are very promising sources of the AP-1 nuclear factor inhibitors, whereas 2 species of Opistobranchia and 3 species of Algae contain activators of the AP-1 activity. We hope that our study will facilitate the further search and isolation of the AP-1 nuclear factor inhibitors and activators from marine sources.

\section{Conclusion}

In conclusion, the extracts of 71 species of marine organisms out of 148 species studied showed inhibitory effects on the AP-1 transcriptional activity in JB6 Cl41 AP-1 cells, and only 12 extracts demonstrated activation of the AP-1 nuclear factor. The search for natural compounds that inhibit or induce AP-1 activity may lead to the development of the new promising preventive or therapeutic drugs against various diseases including cancer.

\section{Acknowledgments}

This work was supported by Grant RFFI 11-04-0052-a, Grant NSS 546.2012.4 from the President of RF, program of presidium of RAS "Molecular and Cell Biology", and FEB RAS Grant 12-III-B-05-020. The authors are grateful to Professor Zigang Dong (Hormel Institute of Minnesota University, USA) who kindly donated the JB6 cell lines, which were used in the present study.

\section{References}

[1] R. Eferl and E. F. Wagner, "AP-1: a double-edged sword in tumorigenesis," Nature Reviews Cancer, vol. 3, no. 11, pp. 859-868, 2003.

[2] M. R. Young, J. J. Li, M. Rincon, and R. A. Flavell, “Transgenic mice demonstrate AP-1 (activator protein-1) transactivation is required for tumor promotion," Proceedings of the National Academy of Sciences of the United States of America, vol. 96, no. 17, pp. 9827-9832, 1999.

[3] E. Shaulian and M. Karin, "AP-1 as a regulator of cell life and death," Nature Cell Biology, vol. 4, no. 5, pp. E131-E136, 2002. 
[4] L. R. Bernstein and N. H. Colburn, "AP1/jun function is differentially induced in promotion-sensitive and resistant JB6 cells," Science, vol. 244, no. 4904, pp. 566-569, 1989.

[5] E. Tulchinsky, "Fos family members: regulation, structure and role in oncogenic transformation," Histology and Histopathology, vol. 15, no. 3, pp. 921-928, 2000.

[6] W. Jochum, E. Passegué, and E. F. Wagner, "AP-1 in mouse development and tumorigenesis," Oncogene, vol. 20, no. 19, pp. 2401-2412, 2001.

[7] P. Angel and M. Karin, "The role of Jun, Fos and the AP-1 complex in cell-proliferation and transformation," Biochimica et Biophysica Acta, vol. 1072, no. 2-3, pp. 129-157, 1991.

[8] Z. Q. Wang, A. E. Grigoriadis, U. Mohle-Steinlein, and E. F. Wagner, "A novel target cell for c-fos-induced oncogenesis: development of chondrogenic tumours in embryonic stem cell chimeras," EMBO Journal, vol. 10, no. 9, pp. 2437-2450, 1991.

[9] Z. Dong, R. G. Watts, Y. Sun, S. N. Zhan, and N. H. Colburn, "Progressive elevation of AP-1 activity during preneoplastic-toneoplastic progression as modeled in mouse JB6 cell variants," International Journal of Oncology, vol. 7, no. 2, pp. 359-364, 1995.

[10] Z. G. Dong, M. J. Birrer, R. G. Watts, and L. M. Matrisian, "Blocking of tumor promoter-induced AP-1 activity inhibits induced transformation in JB6 mouse epidermal cells," Proceedings of the National Academy of Sciences of the United States of America, vol. 91, no. 2, pp. 609-613, 1994.

[11] J. M. Gee, J. F. Robertson, I. O. Ellis, and R. I. Nicholson, "Impact of activation of MAP kinase family members on endocrine and survival in clinical breast cancer," European Journal of Cancer, vol. 36, supplement 4, article 105, 2000.

[12] B. Neyns, E. Teugels, C. Bourgain, M. Birrer, and J. de Greve, "Alteration of Jun proto-oncogene status by plasmid transfection affects growth of human ovarian cancer cells," International Journal of Cancer, vol. 82, no. 5, pp. 687-693, 1999.

[13] B. K. Prusty and B. C. Das, "Constitutive activation of transcription factor AP-1 in cervical cancer and suppression of human papillomavirus (HPV) transcription and AP-1 activity in HeLa cells by curcumin," International Journal of Cancer, vol. 113, no. 6, pp. 951-960, 2005.

[14] H. Wang, M. Birkenbach, and J. Hart, "Expression of Jun family members in human colorectal adenocarcinoma," Carcinogenesis, vol. 21, no. 7, pp. 1313-1317, 2000.

[15] S. Linardopoulos, E. Papadakis, D. Delakas, V. Theodosiou, A. Cranidis, and D. A. Spandidos, "Human lung and bladder carcinoma tumors as compared to their adjacent normal tissue have elevated AP-1 activity associated with the retinoblastoma gene promoter," Anticancer Research, vol. 13, no. 1, pp. 257-262, 1993.

[16] R. Chiu, P. Angel, and M. Karin, "Jun-B differs in its biological properties from, and is a negative regulator of, c-Jun," Cell, vol. 59, no. 6, pp. 979-986, 1989.

[17] E. Passegué, W. Jochum, M. Schorpp-Kistner, U. MöhleSteinlein, and E. F. Wagner, "Chronic myeloid leukemia with increased granulocyte progenitors in mice lacking JunB expression in the myeloid lineage," Cell, vol. 104, no. 1, pp. 21-32, 2001.

[18] H. Le-Niculescu, E. Bonfoco, Y. Kasuya, F. X. Claret, D. R. Green, and M. Karin, "Withdrawal of survival factors results in activation of the JNK pathway in neuronal cells leading to Fas ligand induction and cell death," Molecular and Cellular Biology, vol. 19, no. 1, pp. 751-763, 1999.
[19] T. Kondo, T. Matsuda, T. Kitano et al., "Role of c-jun expression increased by heat shock- and ceramide-activated caspase- 3 in HL-60 cell apoptosis. Possible involvement of ceramide in heat shock-induced apoptosis," The Journal of Biological Chemistry, vol. 275, no. 11, pp. 7668-7676, 2000.

[20] S. Kasibhatla, T. Brunner, L. Genestier, F. Echeverri, A. Mahboubi, and D. R. Green, "DNA damaging agents induce expression of Fas ligand and subsequent apoptosis in T lymphocytes via the activation of NF- $\kappa$ B and AP-1," Molecular Cell, vol. 1, no. 4, pp. 543-551, 1998.

[21] S. K. Manna, N. K. Sah, and B. B. Aggarwal, "Protein tyrosine kinase p56(lck) is required for ceramide-induced but not tumor necrosis factor-induced activation of NF- $\kappa \mathrm{B}, \mathrm{AP}-1$, JNK, and apoptosis," The Journal of Biological Chemistry, vol. 275, no. 18, pp. 13297-13306, 2000.

[22] S. Leppä, M. Eriksson, R. Saffrich, W. Ansorge, and D. Bohmann, "Complex functions of AP-1 transcription factors in differentiation and survival of PC12 cells," Molecular and Cellular Biology, vol. 21, no. 13, pp. 4369-4378, 2001.

[23] A. Gopalakrishnan and A. N. Kong, "Anticarcinogenesis by dietary phytochemicals: cytoprotection by Nrf2 in normal cells and cytotoxicity by modulation of transcription factors NF$\kappa \mathrm{B}$ and AP-1 in abnormal cancer cells," Food and Chemical Toxicology, vol. 46, no. 4, pp. 1257-1270, 2008.

[24] E. F. Wagner and R. Eferl, "Fos/AP-1 proteins in bone and the immune system," Immunological Reviews, vol. 208, pp. 126-140, 2005.

[25] Y. Yan, G.-X. Zhang, M. S. Williams et al., “TCR stimulation upregulates MS4a4B expression through induction of AP1 transcription factor during $\mathrm{T}$ cell activation," Molecular Immunology, vol. 52, no. 2, pp. 71-78, 2012.

[26] G. Raivich and A. Behrens, "Role of the AP-1 transcription factor c-Jun in developing, adult and injured brain," Progress in Neurobiology, vol. 78, no. 6, pp. 347-363, 2006.

[27] M. S. Kindy, J. P. Carney, R. J. Dempsey, and J. M. Carney, "Ischemic induction of protooncogene expression in gerbil brain," Journal of Molecular Neuroscience, vol. 2, no. 4, pp. 217-228, 1991.

[28] R. Zenz and E. F. Wagner, "Jun signalling in the epidermis: from developmental defects to psoriasis and skin tumors," International Journal of Biochemistry and Cell Biology, vol. 38, no. 7, pp. 1043-1049, 2006.

[29] K. W. Kim, J. Im, J. H. Jeon, H.-G. Lee, C.-H. Yun, and S. H. Han, "Staphylococcus aureus induces IL- $1 \beta$ expression through the activation of MAP kinases and AP-1, CRE and NF- $\kappa$ B transcription factors in the bovine mammary gland epithelial cells," Comparative Immunology, Microbiology and Infectious Diseases, vol. 34, no. 4, pp. 347-354, 2011.

[30] V. D. Leaner, H. Donninger, and M. J. Birrer, “Transcription factors as targets for cancer therapy: AP-1 a potential therapeutic target," Current Cancer Therapy Reviews, vol. 3, no. 1, pp. 1-6, 2007.

[31] R. Yu, V. Hebbar, D. W. Kim, S. Mandlekar, J. M. Pezzuto, and A. N. T. Kong, "Resveratrol inhibits phorbol ester and UV-induced activator protein 1 activation by interfering with mitogen-activated protein kinase pathways," Molecular Pharmacology, vol. 60, no. 1, pp. 217-224, 2001.

[32] S. N. Fedorov, S. A. Dyshlovoy, M. M Monastyrnaya et al., "The anticancer effects of actinoporin RTX-A from the sea anemone Heteractis crispa (=Radianthus macrodactylus)," Toxicon, vol. 55 , no. 4 , pp. $811-817,2010$. 
[33] S. N. Fedorov, L. K. Shubina, A. A. Kicha et al., "Proapoptotic and anticarcinogenic activities of leviusculoside $G$ from the starfish Henricia leviuscula and probable molecular mechanism," Natural Product Communications, vol. 3, no. 10, pp. 1575-1580, 2008.

[34] A. Berry, M. Goodwin, C. L. Moran, and T. C. Chambers, "AP-1 activation and altered AP-1 composition in association with increased phosphorylation and expression of specific Jun and Fos family proteins induced by vinblastine in KB-3 cells," Biochemical Pharmacology, vol. 62, no. 5, pp. 581-591, 2001.

[35] M. Fan, M. E. Goodwin, M. J. Birrer, and T. C. Chambers, "The c-Jun $\mathrm{NH}_{2}$-terminal protein kinase/AP-1 pathway is required for efficient apoptosis induced by vinblastine," Cancer Research, vol. 61, no. 11, pp. 4450-4458, 2001.

[36] A. Gopalakrishnan, C. J. Xu, S. S. Nair, C. Chen, V. Hebbar, and A. N. T. Kong, "Modulation of activator protein-1 (AP-1) and MAPK pathway by flavonoids in human prostate cancer PC3 cells," Archives of Pharmacal Research, vol. 29, no. 8, pp. 633-644, 2006.

[37] L. K. Shubina, S. N. Fedorov, O. S. Radchenko et al., "Desmethylubiquinone Q2 from the far-Eastern ascidian Aplidium glabrum: structure and synthesis," Tetrahedron Letters, vol. 46, no. 4, pp. 559-562, 2005.

[38] S. N. Fedorov, O. S. Radchenko, L. K. Shubina et al., "Evaluation of cancer-preventive activity and structure-activity relationships of 3-demethylubiquinone Q2, isolated from the ascidian Aplidium glabrum, and its synthetic analogs," Pharmaceutical Research, vol. 23, no. 1, pp. 70-81, 2006.

[39] S. N. Fedorov, O. S. Radchenko, L. K. Shubina et al., "Anticancer activity of 3-demethylubiquinone Q2. In vivo experiments and probable mechanism of action," Anticancer Research, vol. 28, no. 2A, pp. 927-932, 2008.

[40] C. Huang, W. Y. Ma, M. R. Young, N. Colburn, and Z. Dong, "Shortage of mitogen-activated protein kinase is responsible for resistance to AP-1 transactivation and transformation in mouse JB6 cells," Proceedings of the National Academy of Sciences of the United States of America, vol. 95, no. 1, pp. 156-161, 1998.

[41] J. A. Baltrop, T. C. Owen, A. H. Cory, and J. G. Cory, "5-(3-carboxymethoxyphenyl)-2-(4, 5-dimethylthiazolyl)3-(4-sulfophenyl)tetrazolium, inner salt (MTS) and related analogs of 3-(4, 5-dimethylthiazolyl)-2, 5-diphenyltetrazolium bromide (MTT) reducing to purple water-soluble formazans As cell-viability indicators," Bioorganic \& Medicinal Chemistry Letters, vol. 1, no. 11, pp. 611-614, 1991.

[42] S. N. Fedorov, L. K. Shubina, A. S. Kuzmich, and S. G. Polonik, "Antileukemic properties and structure-activity relationships of $\mathrm{O}$ - and S-glycosylated derivatives of juglone and related 1, 4naphthoquinones," Open Glycoscience, vol. 4, pp. 1-5, 2011.

[43] S. A. Dyshlovoy, S. N. Fedorov, A. I. Kalinovsky et al., "Mycalamide a shows cytotoxic properties and prevents EGF-induced neoplastic transformation through inhibition of nuclear factors," Marine Drugs, vol. 10, no. 6, pp. 1212-1224, 2012.

[44] S. N. Fedorov, S. A. Dyshlovoy, L. K. Shubina, A. G. Guzii, A. S. Kuzmich, and T. N. Makarieva, "C11 cyclopentenone from the ascidian diplosoma sp. prevents epidermal growth factorinduced transformation of JB6 cells," Drugs and Therapy Studies, vol. 2, no. 1, article e4, 2012. 

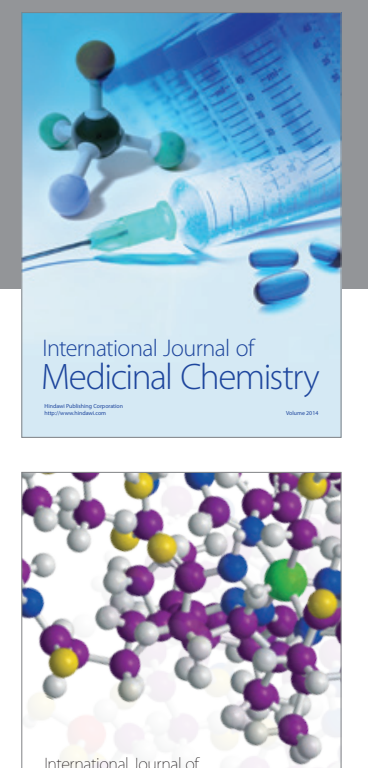

\section{Carbohydrate} Chemistry

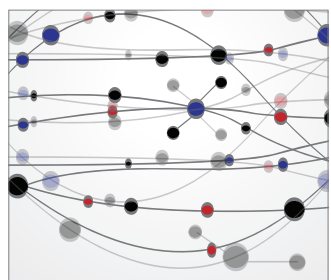

The Scientific World Journal
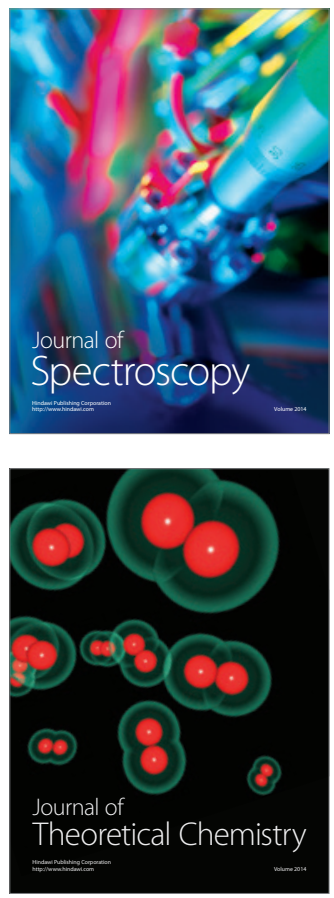
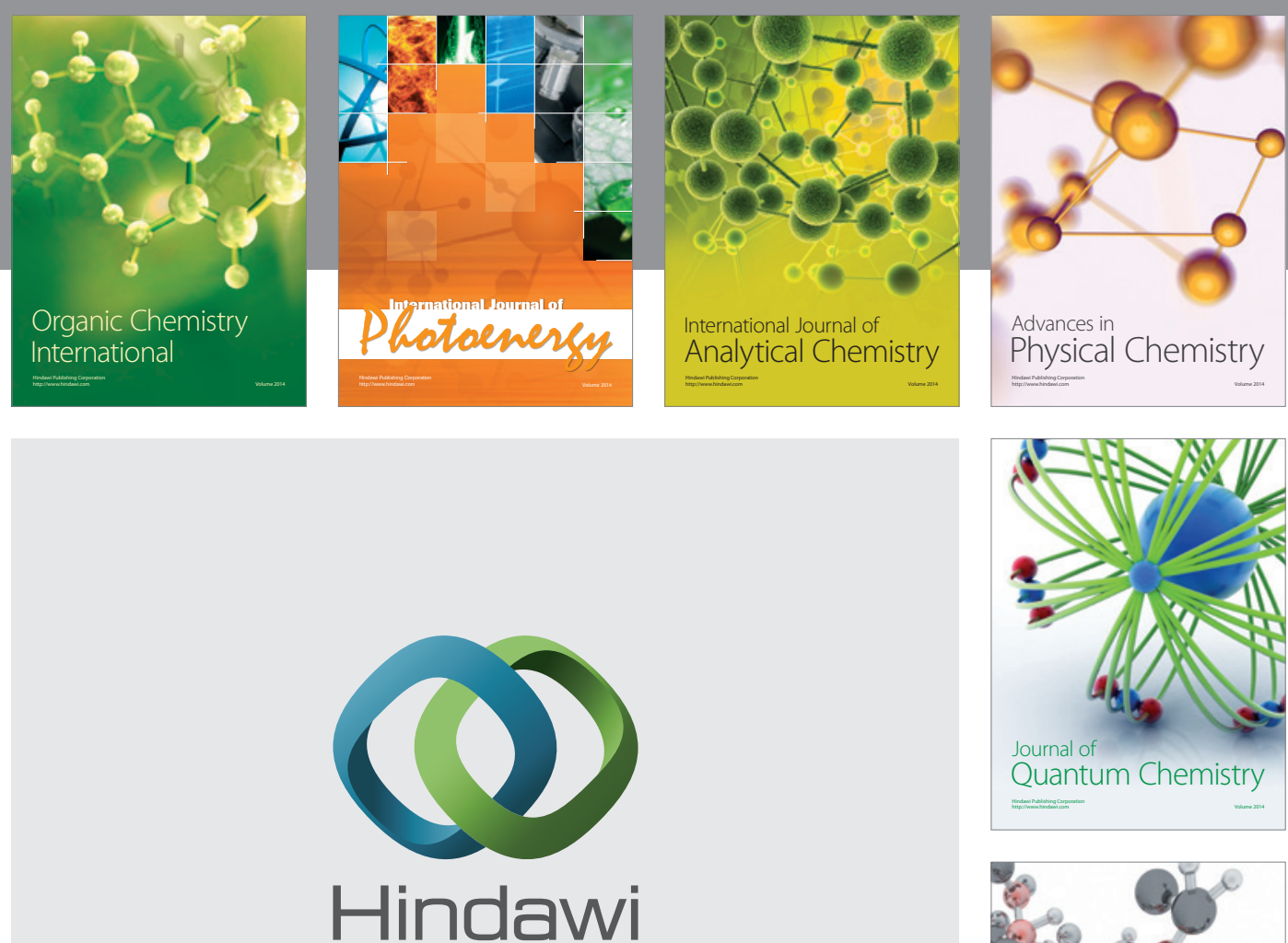

Submit your manuscripts at

http://www.hindawi.com

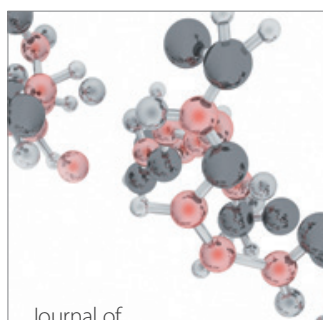

Analytical Methods

in Chemistry

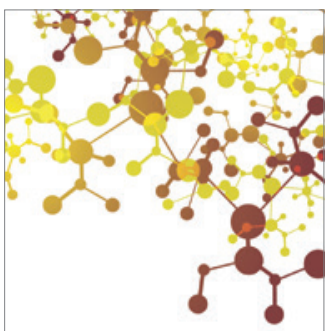

Journal of

Applied Chemistry

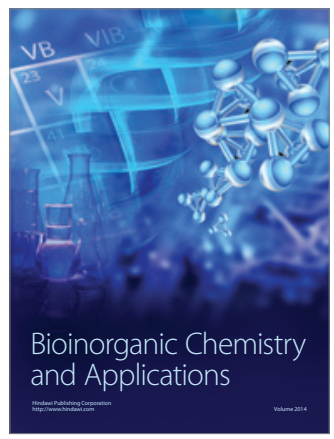

Inorganic Chemistry
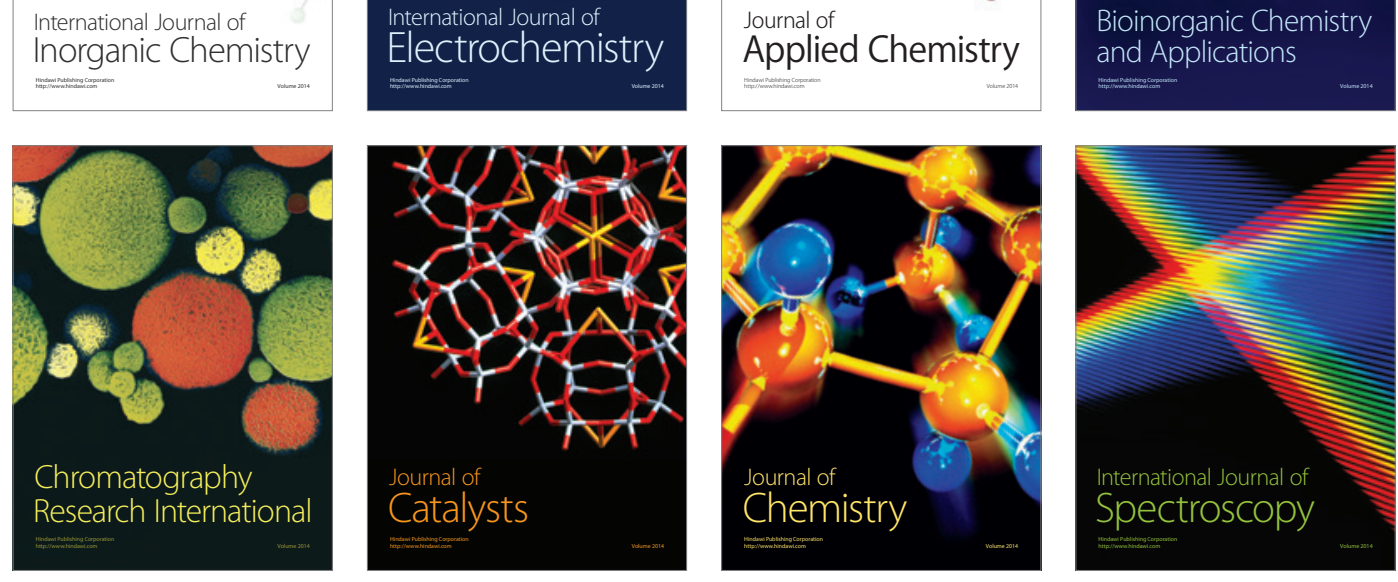